\title{
Sustainability and Conceptual Groundwater Hydraulic Models of Basement Aquifers
}

\section{Trajnost in konceptualni hidravlični modeli podzemne vode v vodonosnikih podlage}

\author{
Olanrewaju Akinfemiwa Akanbi ${ }^{1, *}$, Moshood 'Niyi Tijani² \\ ${ }^{1}$ Department of Earth Sciences, Ajayi Crowther University Oyo, Oyo Town, Nigeria \\ ${ }^{2}$ Department of Geology, University of Ibadan, Ibadan, Nigeria \\ *oa.akanbi@acu.edu.ng
}

\begin{abstract}
Groundwater flow of the basement terrains of the Ibarapa region was studied by carrying out pumping test and measurement of borehole inventory. The view was to identify the associated aquifer systems from the time-drawdown curves, quantify the estimable hydraulic properties and develop hypothetical models for the understanding of the groundwater flow in the area underlain by diverse crystalline bedrocks. Three aquifer types were identified namely, dual, leaky and regolith. The yield of groundwater in dual and leaky aquifers that dominated terrains underlain by amphibolite and gneisses was sustainable, but the discharge of regolith aquifers mainly associated with migmatite and granite terrains declined at late pumping stage. The transmissivities of the dual and leaky aquifers were between 2.02 and $11.65 \mathrm{~m}^{2} /$ day, while those of regolith aquifers were mostly less than $1.00 \mathrm{~m}^{2} /$ day. The average aquifer transmissivities in $\mathrm{m}^{2} /$ day by bedrocks were: $6.85,2.57$, 0.76 and 1.72 , correspondingly. The inter-relationships between transmissivities and groundwater discharge showed diverse aquifer representations, from sustainable high-yielding to unsustainable low-yielding types. Conscientious effort is, therefore, required for well construction in the area.
\end{abstract}

Key words: groundwater, well-inventory, time-drawdown, aquifer-types, yield

\section{Povzetek}

Tok podzemne vode na območju Ibarapa je bil proučevan s pomočjo črpalnih preizkusov in popisov vrtin. Namen članka je indentificirati povezane sisteme vodonosnikov iz krivulj časovnega znižanja gladine podzemne vode, oceniti hidravlične lastnosti in razviti hipotetične modele za razumevanje toka podzemne vode na območju z raznoliko kristalinično kamninsko podlago. Identificirani so bili trije tipi vodonosnikov: dvojni, polzaprti in regolitni vodonosnik. Izdatnost podzemne vode $\mathrm{v}$ dvojnem in polzaprtem vodonosniku, ki prevladujejo in imajo za podlago amfibolit ter gnajs, je bila trajna. Izdatnost regolitnega vodonosnika, ki ima za podlago migmatit in granit, je v pozni fazi črpanja upadla. Transmisivnost dvojnih in polzaprtih vodonosnikov je bila med 2.02 in $11.65 \mathrm{~m}^{2} /$ dan, medtem ko je bila transmisivnost regolitnih vodonosnikov večinoma manj kot $1.00 \mathrm{~m}^{2} /$ dan. Povprečne transmisivnosti vodonosnikov $\mathrm{v} \mathrm{m}^{2} /$ dan glede na omenjene kamninske podlage so bile $6.85,2.57,0.76$ in 1.72 . Povezava med transmisivnostjo in izdatnostjo kaže na raznolika stanja vodonosnikov, od trajnega visoko izdatnega do ne-trajnega nizko izdatnega tipa. Ugotovitve je potrebno upoštevati pri izdelavi vrtin na tem območju.

Ključne besede: podzemna voda, popis vrtin, časovno znižanje gladine podzemne vode, tipi vodonosnikov, izdatnost 


\section{Introduction}

In the Sub-Sahara tropical climatic region of Africa, basement aquifers are of particular importance due to the extensive availability of weathered overburden and/or the occasional occurrences of bedrock fracturing $[1,2]$. Besides, as there is no alternative source of water supply for the increasing population and the developing economies, groundwater has become the major reliable water resource for both domestic and industrial usages [3, 4]. However, the yield of basement aquifers is known to be generally poor and erratic as a result of the discrepancy in the structural and textural systems $[4,5]$ associated with the crystalline basement of igneous and/or metamorphic rocks.

In respect of this, the Nigerian hydrogeological setting is complex because approximately half of the landmass is underlain by diverse intrusive crystalline rocks $[6,7]$ including the Ibarapa region, which is within the southwestern (SW) Nigeria basement complex. The study lies inside coordinates- $7^{\circ} 21^{\prime} \mathrm{N}-7^{\circ} 37^{\prime} \mathrm{N}$ and $3^{\circ} 07^{\prime}$ $\mathrm{E}-3^{\circ} 21^{\prime} \mathrm{E}$ (Figure 1) and has human population that is well above 200,000 [8]. At the moment, towns and adjoining communities have no functioning town water supply $[3,4]$, and the residents of the Ibarapa region rely on groundwater for domestic water needs and even for agricultural purposes. The groundwater is supplied from hundreds of hand pump boreholes that tapped into the weathered-regolith and underlying bedrocks, which include granite, gneisses, amphibolite and migmatite [4] (Figure 2). These boreholes were largely funded by the government and other foreign agencies under the water supply and sanitation scheme for rural communities' development (formerly WATSAN) [3]. However, even with these provisions, the availability of potable water is still inadequate as a result of unsustainable yield and improper management. Recently in the study area, there is a dire need to expand the groundwater supply due to the increasing population, the unavailability of town water supply and the poor yield of most of the drilled wells. Hence, it is now mandatory to characterise the sustainable yield of the aquifer systems across the various bedrocks terrains within the Ibarapa region of SW Nigeria to ensure the effective

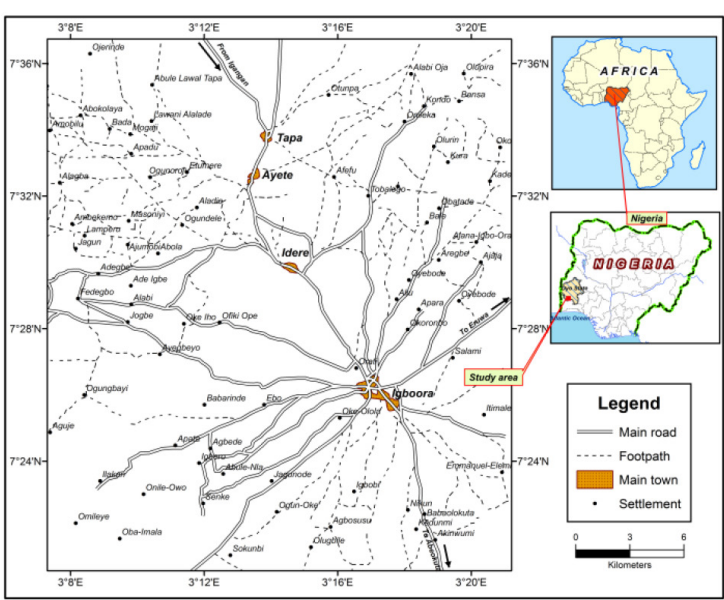

Figure 1: Location map of the study area.

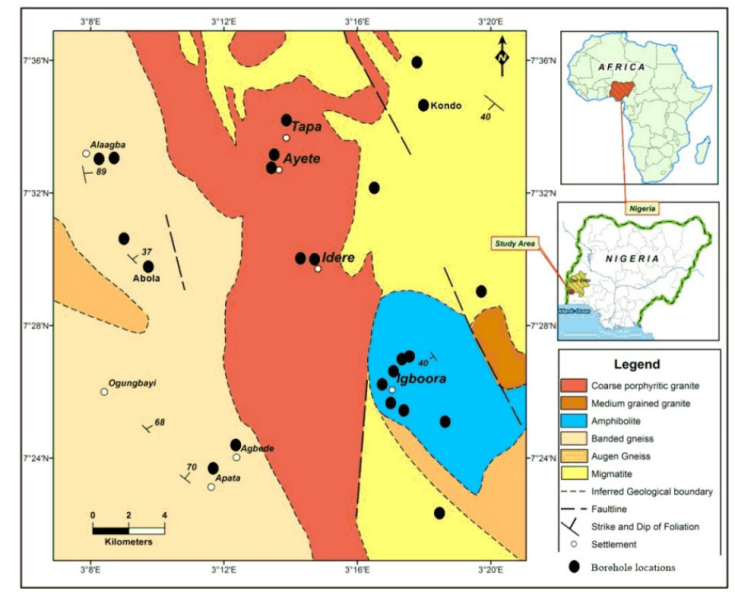

Figure 2: Geological map of the study area with wells' points.

management and sustainable groundwater resources.

For the appropriate analyses of the aquifer system, pumping tests provide enough information in evaluating the safe yield of an aquifer and estimating aquifer properties like transmissivity[9]. However, despite the importance of hydraulic characterisation, documented or published reports of aquifer characterisation using pumping tests are scarce in developing nations like Nigeria due to cost factor and lack of technical expertise in analysing pumping and recovery tests data. Because the essential aquifer properties, like transmissivity, can be reliably estimated from single-well test and that there is no need for observation wells [10], make it appropriate for the present study, this method is less cumbersome and relatively 
less expensive to conduct as compared to others. Moreover, single-well pumping tests can provide hydraulic conditions of a local aquifer system. It is, therefore, suitable for characterising the basement aquifers of the Ibarapa region where the hydrogeology is expected to be complex as a result of lithological and structural complications $[11,12]$, even within the same bedrock terrain.

\section{Materials and Methods}

The hydraulic characterisation of the crystalline aquifers of the Ibarapa regions was carried out by conducting single-well pumping tests on 23 wells across the various bedrocks terrains within the study areas. Seven wells were tested on terrains underlain by amphibolite, six on gneisses, and five each in areas underlain by both migmatite and porphyritic granite (Figure 2).

Before the pumping tests were conducted, well inventory, including coordinates, pre-pumping level and the elevation and depth of the well were taken. The measurable and estimable hydraulic properties from single-well pumping included the water table, discharge, change in drawdown per log cycle of time, total drawdown for the entire pumping time and transmissivity. The discharge $(\mathrm{Q})$, which is the groundwater yield, was measured at every time interval in cubic metre per day to an accuracy of $0.0001 \mathrm{~m}^{3}$ (or 0.1 l). The static water level and the depths of individual wells were measured using the automatic water level and a well-depth indicator. In most cases, the drawdowns were measured every $30 \mathrm{~s}$ for the first $5 \mathrm{~min}$. The time intervals were then increased as pumping continues. The wells were pumped continuously till steadystate conditions were reached. When discharge is no longer sustainable with the same constant discharge, the yield can no longer support the rate of discharge and the aquifer is unsustainable.

The total drawdown is the difference between the final drawdown in the well after pump cessation and the pre-pumping water level, while the drawdown per log cycle $(\Delta s)$ is the drawdown for one log cycle of pumping time. The unit of measurement of transmissivity is $\mathrm{m}^{2} /$ day. The coordinates of wells were taken using Garmin Etrex GPS, and all field measurements were carried out using the following standard procedures [10].

\section{Data Processing}

For single-well test where no piezometer is used, only the time-drawdown curve is applicable. The semi-log plot is reputable to be more diagnostic of the aquifer characteristics than the log-log scale plots $[10,4]$. The drawdowns are plotted on a vertical linear scale and time on the log scale on the horizontal axis. From the semi-log plots, the flow regimes and aquifer boundary can be identified and analysed using the appropriate equations. Typical aquifer boundary conditions have been defined from the time-drawdown curves by various workers $[10,9,13]$.

For the present work, Jacob's straight-line method is applicable for the analysis of the time-drawdown data from the single-well pumping test. This method does not require the correction for non-linear well losses and can be used to analyse the time-drawdown data obtained from the single-well test for both confined and leaky aquifers [10]. From the straightline plot obtained from the semi-log graph of drawdowns against time, the transmissivities, $T$ of the aquifers, were estimated using the following equation:

$T=2.3 \mathrm{Q} / 4 \pi \Delta s[14]$

where $Q=$ pumping rate and $\Delta s=$ drawdown across one log cycle. From this approach of study, theoretical hydraulic models of the basement aquifers of the study area were then developed from the cross-plots of aquifers' transmissivities and yields. The statistical evaluation and cross-plots were also constructed to establish the type and degree of inter-relationships existing between well inventory and estimated hydraulic parameters.

\section{Results and discussion}

\section{Aquifer Systems}

From the response of the aquifer to pumping on the time-drawdown diagnostic curves as 


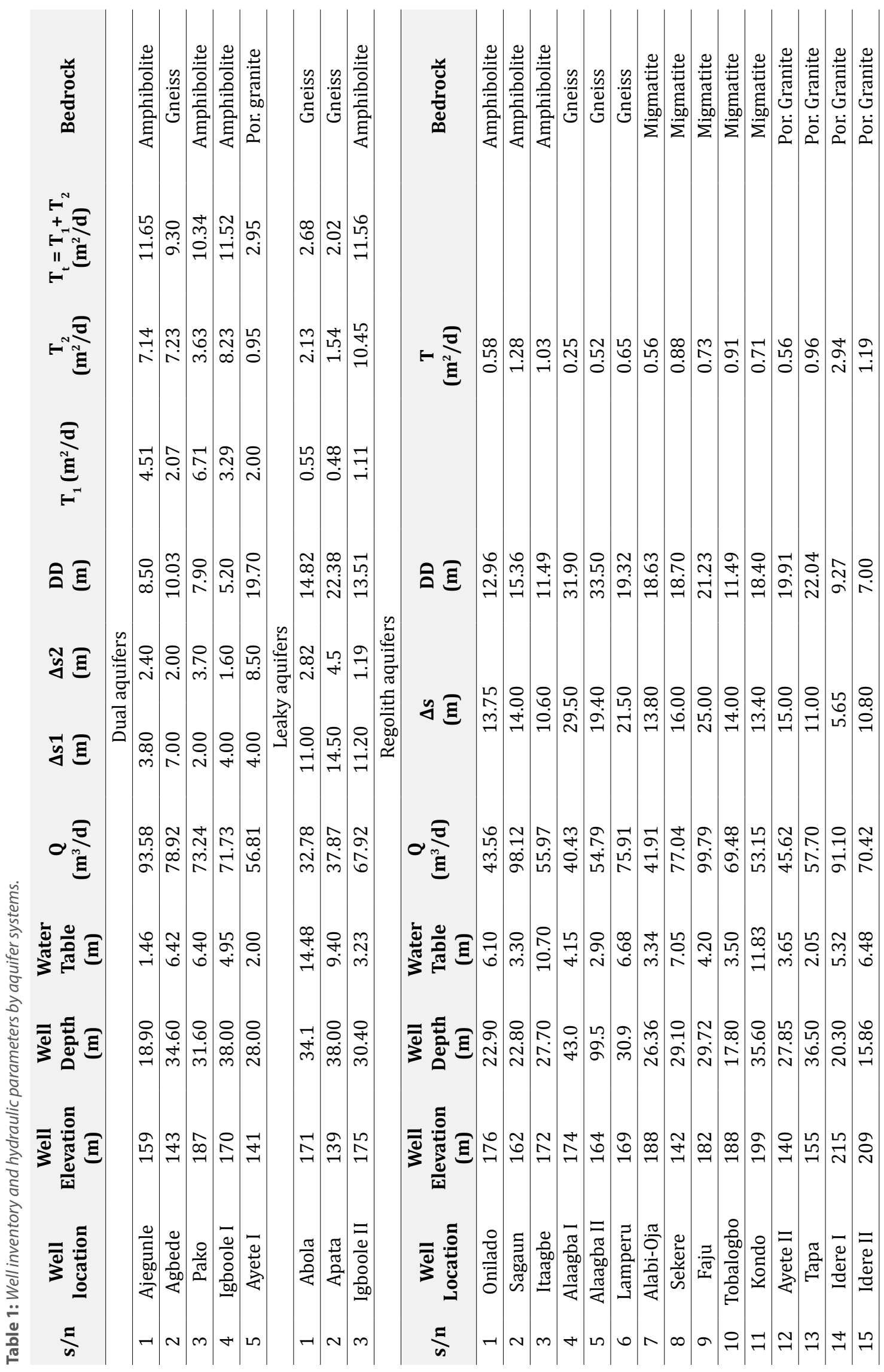


presented in Figures 3 (A) to (C), three aquifer categories were identified, namely, the double porosity (dual), leaky and unconsolidated/ regolith aquifers. The measured and estimated well inventory and hydraulic properties of the aquifer systems that included discharge (Q), drawdown per log cycle $(\Delta s)$, total drawdown (DD) and transmissivity (T) are presented in Table 1.

\section{Dual Aquifers}

Aquifer systems with this type of time-drawdown curves (Figure 3A) are consolidated fractured aquifers of double porosity type $[10,4]$, denoted as dual aquifers in this study, because they are characterised by two distinct flow regimes separated by a transition period (Figure 3A). Each flow regime represents a water-bearing zone that is clearly distinguishable from the other one. The early pumping time signifies water contribution solely from the fractured system. This is succeeded by a transition zone and significant water contribution from the overlying weathered layer at the later pumping time. For dual aquifers, the transmissivity of each flow regime is independently analysed within the domain of its drawdown intervals. The total transmissivity, $\mathrm{T}_{t}$ is the sum of the transmissivities of the upper and the lower aquifers [15] denoted by $\mathrm{T}_{1}$ and $\mathrm{T}_{2}$ respectively as given in Table 1 . Dual aquifer systems are generally characterised by good groundwater yield that is sustainable for the entire pumping period and relatively larger transmissivity (Table 1). Generally, in most of the dual aquifer systems, the transmissivities of the second flow regime are larger because the overlying matrix units also contributed water just as the fractured bedrocks. The occurrence of dual aquifer systems revealed that multi-layer water-bearing zones can develop in basement terrains.

\section{Leaky Aquifers}

Leaky aquifers are characterised by prolific highly permeable densely fractured bedrock underlying the weathered/regolith units. As typical of leaky aquifers, the diagnostic semi-log plots for these aquifers were notably characterised by the development of dynamic-equilibrium at late time (Figure 3B). The equilibrium state is characterised by flattened drawdown at
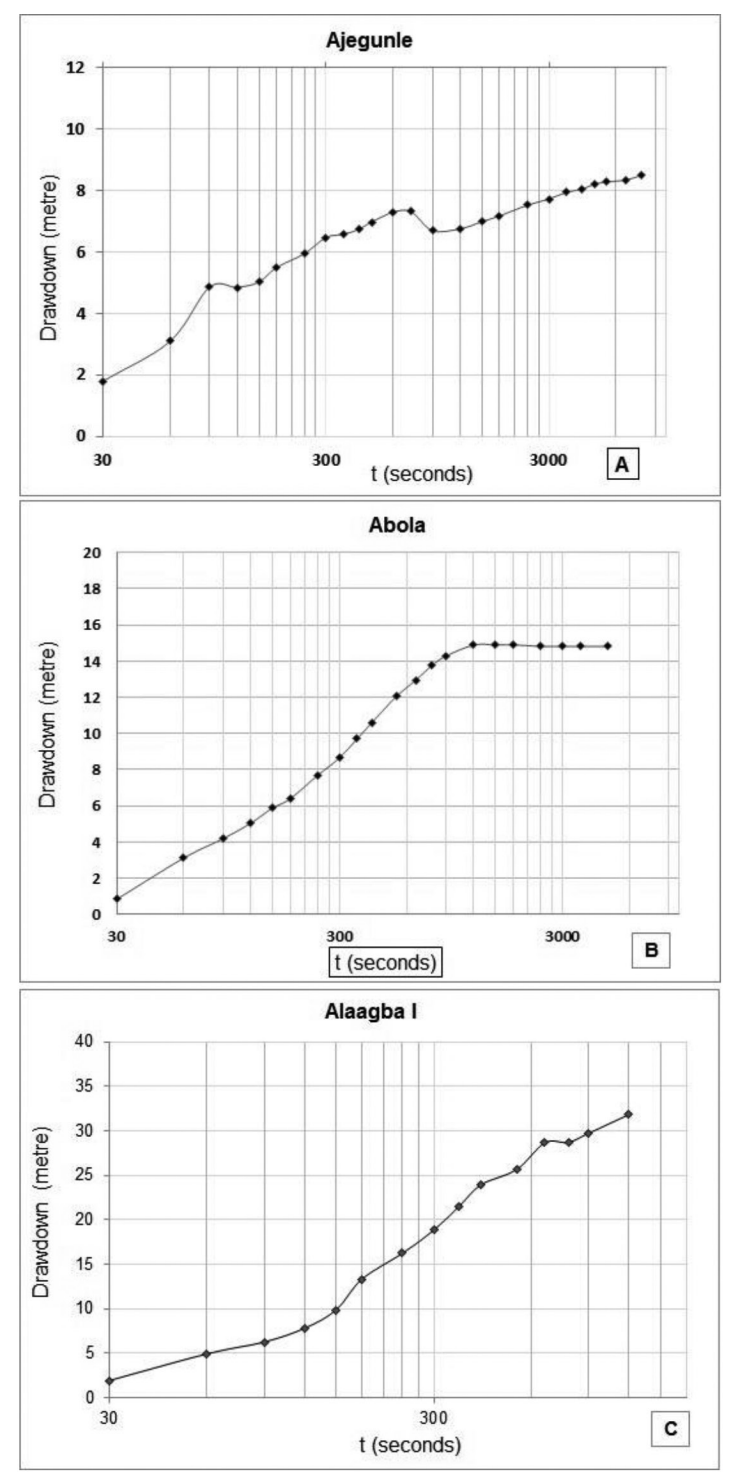

Figure 3: Typical time-drawdown semi-log plots obtained for: (A) dual aquifers, (B) leaky aquifers and (C) regolith aquifer systems.

the late pumping stage regardless of the length of pumping. These wells were found at Abola, Apata and Igboole II. This type of aquifer system is somehow referred to as semi-confined aquifers whereby the overlying regolith is an aquitard and also permeable, though not as prolific as the fractured bedrock under it.

\section{Regolith Aquifers}

Regolith aquifers are the water-bearing weathered layers that developed upon the impermeable or slightly fractured bedrock units. The in-situ regolith units (or the weathered 
Table 2: Statistical summary of well inventory and hydraulic parameters by aquifer systems.

\begin{tabular}{|c|c|c|c|c|c|c|c|c|}
\hline $\begin{array}{l}\text { Aquifer } \\
\text { systems }\end{array}$ & $\mathbf{n}$ & Statistics & 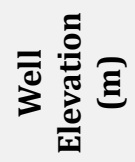 & 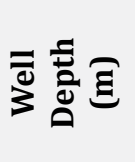 & 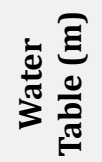 & $\begin{array}{c}\text { Discharge } \\
Q \\
\left(\mathrm{~m}^{3} / \mathrm{d}\right)\end{array}$ & $\begin{array}{c}\text { Total } \\
\text { drawdown } \\
\text { (m) }\end{array}$ & $\begin{array}{c}\text { Transmissivity } \\
\text { T } \\
\left(\mathrm{m}^{2} / \mathrm{d}\right)\end{array}$ \\
\hline \multirow{4}{*}{ Dual } & \multirow{4}{*}{5} & Min & 141 & 18.90 & 1.46 & 56.81 & 5.20 & 2.95 \\
\hline & & Max & 187 & 38.00 & 6.42 & 93.58 & 19.70 & 11.65 \\
\hline & & Mean & 160 & 30.22 & 4.25 & 74.86 & 10.27 & 9.15 \\
\hline & & Std.Dev. & 19 & 7.33 & 2.38 & 13.28 & 5.56 & 3.60 \\
\hline \multirow{4}{*}{ Leaky } & \multirow{4}{*}{3} & Min & 139 & 30.40 & 3.23 & 32.78 & 13.51 & 2.02 \\
\hline & & Max & 175 & 38.00 & 14.48 & 67.92 & 22.38 & 11.56 \\
\hline & & Mean & 162 & 34.17 & 9.04 & 46.19 & 16.90 & 5.42 \\
\hline & & Std.Dev. & 20 & 3.80 & 5.63 & 18.99 & 4.79 & 5.33 \\
\hline \multirow{4}{*}{ Regolith } & \multirow{4}{*}{15} & Min & 140 & 15.86 & 2.05 & 40.43 & 7.00 & 0.25 \\
\hline & & Max & 215 & 99.50 & 11.83 & 99.79 & 33.50 & 2.94 \\
\hline & & Mean & 176 & 32.39 & 5.42 & 65.00 & 18.08 & 0.92 \\
\hline & & Std.Dev. & 22 & 19.92 & 2.82 & 20.10 & 7.47 & 0.62 \\
\hline
\end{tabular}

layers) that developed upon the intrusive bedrock in the tropical climatic Sub-Sahara region of Africa are somewhat porous and permeable $[1,3,4,5,12]$. From the time-drawdown curves (Figure 3C), wells in this category were dominated initially by water from well storage, and afterward by flows from the matrix component (or weathered layer). The water input from the regolith units was, however, not substantial enough to guarantee the constant discharge for the entire pumping period. Therefore, the discharge dropped at the later stage of pumping. This is noticeable by the sharp decline in drawdown $(\Delta s)$ as water table drops (Figure $3 C$ ).

The yield of regolith aquifers was between 40.43 and 99.79 (av. of 65.00 ) $\mathrm{m}^{3} /$ day, and the drawdowns in the wells were typically large ranging from $7 \mathrm{~m}$ to over $33 \mathrm{~m}$ at an average of $18.08 \mathrm{~m}$ (Table 2). The transmissivities of most of the regolith aquifers were typically below $1.50 \mathrm{~m}^{2} /$ day with an average of $0.92 \mathrm{~m}^{2} /$ day (Table 2). In regard to the transmissivity and the abrupt decline of water level during pumping, the regolith aquifer system is not regarded as being sustainable. Regolith aquifers are the most widespread, found in all terrains; however, they are more common in migmatite and granite terrains.

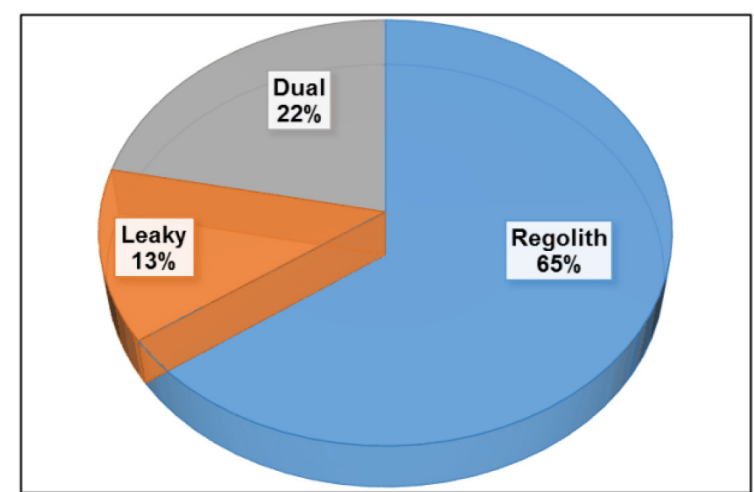

Figure 4: Percentage frequency of aquifers occurrences.

The frequency of the occurrence of regolith aquifer system was 15 , which was about $65 \%$ of the total number of tested wells. The frequency of the dual aquifer system was 5 representing $22 \%$ of occurrences, while that of leaky aquifers was just 3 , which is just about $13 \%$ of occurrences (Figure 4). The fact that the occurrence of regolith aquifers is higher due to the shortage of water supply in the study area.

\section{Bedrocks and Associated Aquifer Systems}

The general statistics of the well inventory data and hydraulic properties by bedrocks is pre- 
Table 3: Statistics of well inventory and hydraulic parameters by bedrocks.

\begin{tabular}{|c|c|c|c|c|c|c|c|c|}
\hline Bedrock & $\mathbf{n}$ & Statistics & 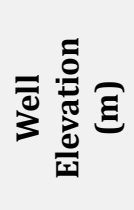 & 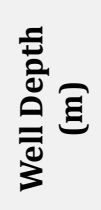 & $\underset{\frac{\pi}{\pi}}{\frac{0}{2}}$ & $\begin{array}{c}Q \\
\left(\mathrm{~m}^{3} / \text { day }\right)\end{array}$ & 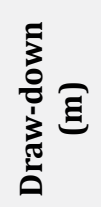 & $\begin{array}{c}T \\
\left(\mathrm{~m}^{2} / \text { day }\right)\end{array}$ \\
\hline \multirow{4}{*}{ Amphibolite } & \multirow{4}{*}{7} & Min. & 159.00 & 18.90 & 1.46 & 43.56 & 5.20 & 0.58 \\
\hline & & Max. & 187.00 & 38.00 & 10.70 & 98.12 & 15.36 & 11.65 \\
\hline & & Mean & 171.57 & 27.47 & 5.16 & 72.02 & 10.70 & 6.85 \\
\hline & & Std dev. & 9.32 & 6.49 & 3.00 & 19.29 & 3.61 & 5.53 \\
\hline \multirow{4}{*}{ Gneisses } & \multirow{4}{*}{6} & Min. & 139.00 & 30.90 & 2.90 & 32.78 & 10.03 & 0.25 \\
\hline & & Max. & 174.00 & 99.50 & 14.48 & 78.92 & 33.50 & 9.30 \\
\hline & & Mean & 160.00 & 46.68 & 7.34 & 53.45 & 21.99 & 2.57 \\
\hline & & Std dev. & 15.13 & 26.20 & 4.16 & 19.97 & 9.30 & 3.43 \\
\hline \multirow{4}{*}{ Migmatite } & \multirow{4}{*}{5} & Min. & 142.00 & 17.80 & 3.34 & 41.91 & 11.49 & 0.56 \\
\hline & & Max. & 199.00 & 35.60 & 11.83 & 99.79 & 21.23 & 0.91 \\
\hline & & Mean & 179.80 & 27.72 & 5.98 & 68.27 & 17.69 & 0.76 \\
\hline & & Std dev. & 22.00 & 6.49 & 3.59 & 22.33 & 3.65 & 0.14 \\
\hline \multirow{4}{*}{$\begin{array}{l}\text { Porphyritic } \\
\text { Granite }\end{array}$} & \multirow{4}{*}{5} & Min. & 140.00 & 15.86 & 2.00 & 45.62 & 7.00 & 0.56 \\
\hline & & Max. & 215.00 & 36.50 & 6.48 & 91.10 & 22.04 & 2.95 \\
\hline & & Mean & 172.00 & 25.70 & 3.90 & 64.33 & 15.58 & 1.72 \\
\hline & & Std dev. & 37.05 & 7.95 & 1.99 & 17.35 & 6.91 & 1.14 \\
\hline
\end{tabular}

sented in Table 3. It is clearly seen that based on the average values as illustrated in Figure 5, groundwater discharge of amphibolite, migmatite and porphyritic granite terrains exceeded $60 \mathrm{~m}^{3} /$ day, while gneissic aquifers have the lowest average yield of nearly $54 \mathrm{~m}^{3}$ /day (Table 3 , Figure 5A). Consequently, the total drawdown in gneisses is the largest, and the average value is greater than $20 \mathrm{~m}$ while it is below $18 \mathrm{~m}$ for other bedrocks (Table 3, Figure 5B). This does not necessarily mean that wells in gneisses are less productive because wells in gneisses are deeper (Table 3 ) as a result of pronounced weathering [14]. The transmissivities of aquifers in amphibolite are relatively larger with a range of $0.58-11.65 \mathrm{~m}^{2} /$ day and an average of $6.85 \mathrm{~m}^{2} /$ day, as compared to those in other terrains having a range of $0.25-9.30 \mathrm{~m}^{2} /$ day, (Table 1, Figure 5C). Amphibolite aquifers have the highest potential for the provision of prolific wells within the study area. The transmissivities of four of the aquifers is greater than $10 \mathrm{~m}^{2} /$ day. Six wells were tested in areas underlain by gneisses. The two wells located at Alaagba and the one tested at Lamperu are regolith and terminate on fresh gneissic bedrocks [12]. The transmissivities ranged from 0.25 to $0.65 \mathrm{~m}^{2} /$ day (Table 3). Wells at Abola, Apata and Agbede were characterised by water-bearing matrix and bedrock. However, the aquifer at Agbede is the most prolific aquifer within the gneissic terrain with transmissivity of $9.03 \mathrm{~m}^{2}$ /day (Table 1). Generally, the mean transmissivity of wells in gneissic terrains is $2.57 \mathrm{~m}^{2} /$ day. This value is comparatively lower than the average value of $6.85 \mathrm{~m}^{2} /$ day estimated for amphibolite aquifers (Table 3). The dynamic equilibrium water level was obtained at Agbede, Abola and Apata at corresponding depths of $10.03 \mathrm{~m}, 14.82 \mathrm{~m}$ and $22.38 \mathrm{~m}$. The dynamic equilibrium water level of aquifers in gneisses is deeper than those in amphibolite. The depth of dynamic equilibrium is less than $9 \mathrm{~m}$ except at Igboole II for aquifers in amphibolite. Water-bearing zones tested on migmatite terrain are similar, and all the five wells penetrated regolith aquifers (Figure 6). The migmatite aquifers are characterised by fairly large 

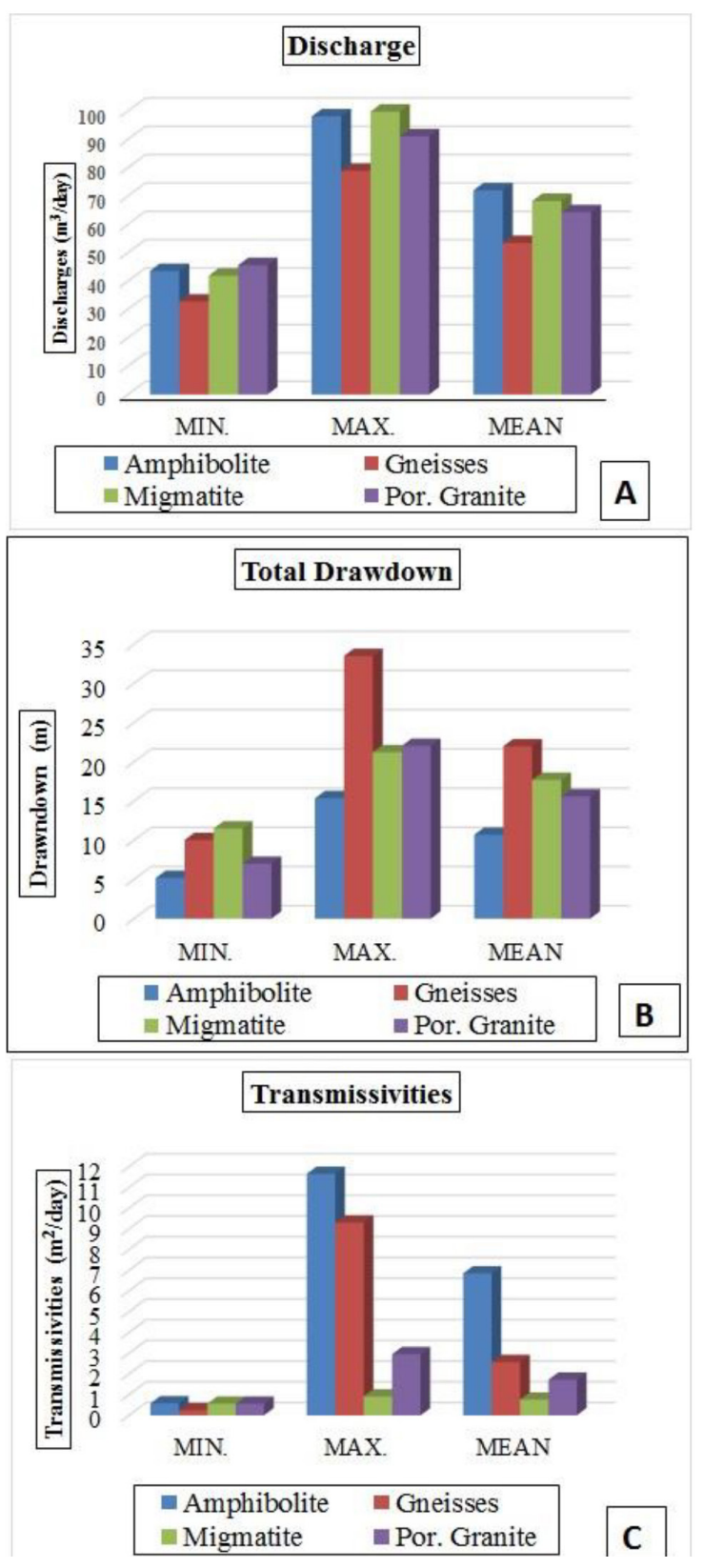

Figure 5: Statistical illustrations of aquifer parameters.

discharge and drawdowns with the average values of $68.27 \mathrm{~m}^{3} /$ day and $17.69 \mathrm{~m}$ (Table 3), respectively. Comparatively, the water-bearing zones in the migmatite terrain have the lowest transmissivity between 0.56 and $0.91 \mathrm{~m}^{2} /$ day and the mean value of $0.76 \mathrm{~m}^{2} /$ day (Table 3 ).

Granitic aquifers are still fairly better than those in migmatite but not as prolific as those in amphibolite and gneisses. The only sustainable well tested on the granitic terrain was Ayete I. The two wells tested at Idere are also

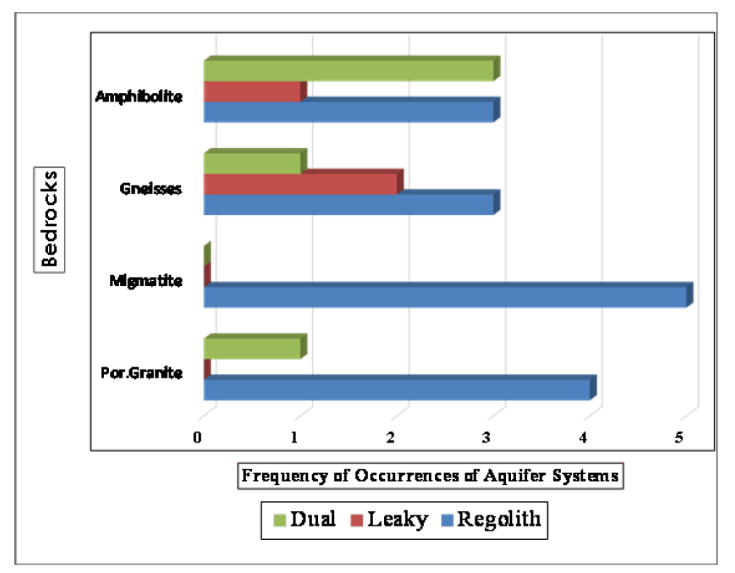

Figure 6: Frequency of occurrences of aquifer systems in bedrocks.

on the granitic terrain with transmissivities of 2.94 and $1.19 \mathrm{~m}^{2} /$ day, respectively; they are not sustainable over a large period of pumping as Ayete I. The rates of pumping rapidly decline during pumping at Idere.

In general, the widespread occurrence of the regolith aquifer is an indication of rarity and localised nature of dual and leaky aquifers in the study area (Figure 4). This is a result of the infrequency of bedrock fractures in the area as revealed by the previous work on lithological and structural mapping of the subsurface environment of the study area using a geophysical method $[4,12]$. Dual aquifers with about $22 \%$ of occurrences are mostly associated with amphibolite terrains (Figure 6). A leaky aquifer is the least occurring aquifer system with just $13 \%$ found in both amphibolite and gneisses. The dynamic water level developed in eight wells during the pumping phase. Four out of eight wells were on amphibolite terrains located at Ajegunle, Pako, Igboole I and II; three on gneissic terrains located at Apata, Abola and Agbede, and the last one on porphyritic granite bedrock terrains located at Ayete I. From the frequency of aquifer systems by bedrock (Figure 6), the dual and leaky aquifers are mostly associated with amphibolite and gneisses terrains. These aquifer systems supplied water at constant discharge and are characterised by low to minimal drawdowns during the entire pumping period. Aside from the nature of aquifer systems, another reason for the occurrence of more successful wells in amphibolite and gneisses was the hydro-geomorphic situations, 
whereby the high-lying terrains mainly underlain by migmatite and granite are the recharge areas, whereas the low-lying terrains that are mostly underlain by amphibolite and gneisses are the discharge areas $[4,16]$.

\section{Influence of Well Inventory on Transmissivity in Various Bedrocks}

The plots of the transmissivities against well inventory along with the results of correlation coefficients (R) between transmissivities against well inventory are presented in Figure 7. The relationship between the aquifer transmissivities and well elevation is positive in amphibolite and granite but negative in migmatite and gneisses. The significance of this association is high only in gneisses, moderate in migmatite, low in granite and insignificant in amphibolite (Figure 7A). This shows that the relief of the well has little or no relevance to the aquifer transmissivities in amphibolite, whereas it does in other bedrocks, particularly in gneisses where $R=-0.62$. It is also deduced that the topography of a well does not have a significant effect on the drawdown and groundwater yield in amphibolite terrain (with $R=0.08$ ). This is because the transmissivity of the aquifer is a function of the groundwater yield and drawdown during pumping. However, in migmatite, these hydraulic properties are moderately influenced by well relief with $R=-048$. This relationship is weak in porphyritic granite with $R=0.27$ (Figure 7A). Moreover, the strong and moderate indirect relationships correspondingly obtained for gneisses and migmatite indicate that wells situated at low-lying areas will be characterised by fairly large transmissivity within these terrains. However, the wells on high-lying areas will be more likely to be prolific in the granitic terrain where the relationship is positive. This is corroborated by the wells at Idere on higher relief $>200 \mathrm{~m}$ (Table 1 ) underlain by granite. The two tested wells were characterised by large discharge and higher transmissivity of 2.95 and $1.19 \mathrm{~m}^{2} /$ day as compared to other wells on the granitic terrain.

The relationship between aquifer transmissivities and well depths is illustrated in Figure 7B. The relationship is direct and moderate in amphibolite terrain while it is indirect for other bedrock terrains. The indirect relation-
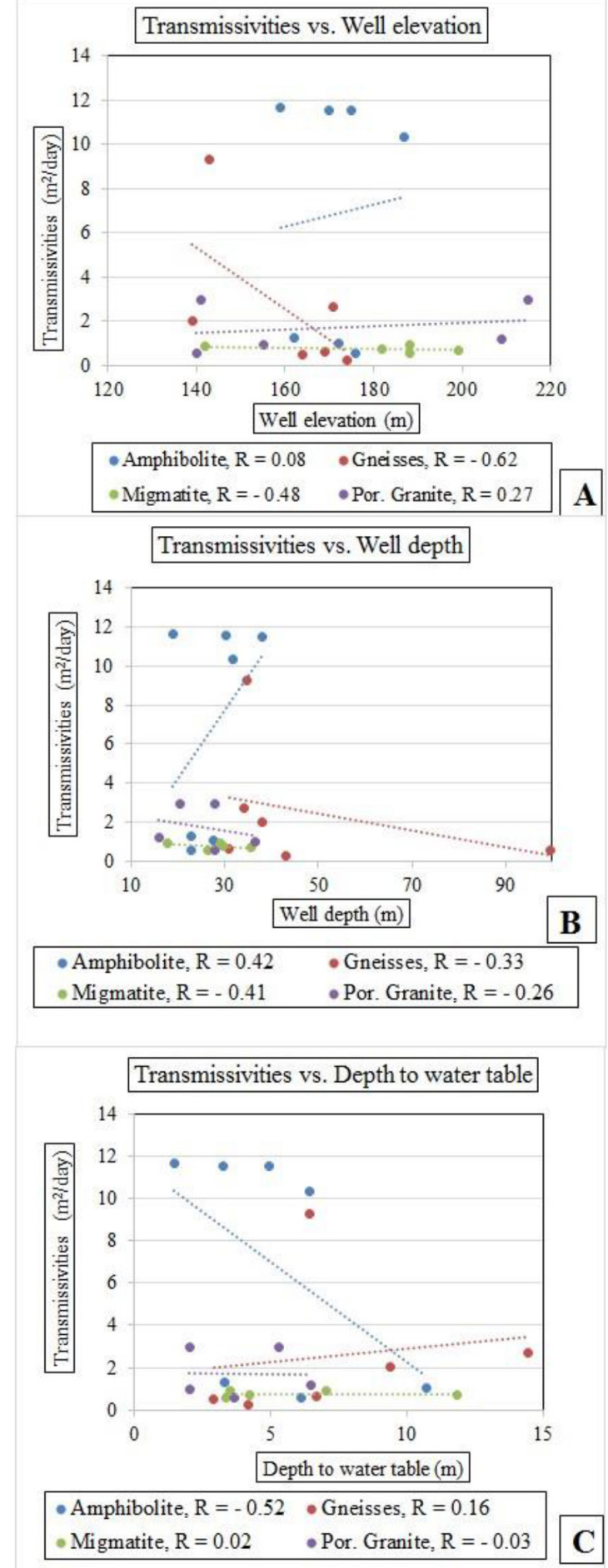

Figure 7: Cross-plots and $R$ coefficients of (A) transmissivity against wells' elevations, (B) transmissivity versus wells' depths and $(C)$ transmissivity against water table by bedrocks.

ship is low for gneisses and porphyritic granite $(R=-0.33$ and -0.26 , respectively). This implies that deep wells will not improve hydrau- 
lic properties in gneisses and in granite, and to a larger extent in migmatite bedrocks where $R=-0.41$. However, the positive moderate relationship in amphibolite with $R=0.42$ indicates that deep wells are expected to be more prolific in amphibolite. This is supported by the fact that amphibolite terrains have prominent occurrences of dual aquifer systems, which is an indication of the extensive subsurface weathering and fracturing [12]. However, shallow wells may also be prolific within amphibolite, like the well at Ajegunle (Tables 1). Normally, terrains underlain by gneisses were notably characterised by deeper wells with depth range of 30.9-99.5 m (Table 3). The linear relationship occurring between transmissivities and wells' depths is weak and indirect $(R=-0.33$; Figure 7B). This suggests that deep wells in gneissic bedrock terrains will not give large water transmission. This was buttressed by wells at Alaagba, where deeper wells did not have a positive effect on the transmission capacity of the aquifers with transmissivities of 0.25 and $0.55 \mathrm{~m}^{2}$ /day correspondingly for Alaagba I and II. However, other gneissic wells with depths between 34 and $36 \mathrm{~m}$ at Apata, Abola and Agbede were prolific. Hence, there is no guarantee of striking a fracture zone at depth beyond this range on gneissic terrains. This is also the case for wells in migmatite. The relationship is also indirect with $R=-0.41$ (Figure 7B), which means that deep wells will not necessarily be prolific as well. Similarly, the $R$ relationship between transmissivities and well depths in granite is indirect, and the strength of relationship is low $(R=-0.26)$ (Figure 7B). This explains the reason for a sharp drop in discharge for wells at Idere. Notably, the wells in granite are shallower (with the average depth of $25.7 \mathrm{~m}$ ), compared to the averages of $27.47 \mathrm{~m}, 46.68 \mathrm{~m}$ and $27.72 \mathrm{~m}$ correspondingly for wells in amphibolite, gneisses and migmatite terrains (Table 3). The $R$ value and the relatively shallower wells within granitic terrains indicated less weathering and infrequency of bedrock fractures within granitic terrains [12].

The only significant relationship existing between the aquifer transmissivities and the groundwater table in Figure 7C is within the amphibolite terrains with $R=-0.52$. This relationship is indirect and moderate. Shallow groundwater table is an indication of high aquifer pressure, which is most likely in amphibolite, whereby the regolith units are largely fine grained, and are acting as aquiclude over the largely fractured bedrock $[3,12]$. This creates a confined aquifer system in amphibolite and the groundwater system is under pressure, leading to likely occurrences of artesian aquifers within this bedrock. The strength of the relationships between transmissivities and groundwater table is insignificant in other bedrocks (Figure 7C).

\section{Groundwater Yield and Aquifer Sustainability}

Eight wells located at Ajegunle, Igboole II, Igboole I, Pako, Agbede, Ayete I, Abola and Apata out of all tested boreholes are prolific and sustainable (Figure 8) due to comparatively larger transmissivity, smaller drawdown and constant discharge during the entire pumping period. The wells are either leaky or dual aquifer categories and are mainly restricted to terrains underlain by amphibolite and gneisses. The first four wells with the largest transmissivity within the range of $11.65-9.30 \mathrm{~m}^{2} /$ day are within amphibolite terrain. Wells at Agbede, Abola and Apata are on the gneissic bedrock, while Ayete I is the only prolific well tested on the porphyritic granite terrain.

Aside from the sustainable yield of leaky and dual aquifers, the water level attained a dynamic equilibrium level at the late pumping stage. These aquifers supplied water to the wells from the matrix/weathered layer and the fractured bedrocks. The depths of these prolific wells that penetrated the dual and leaky aquifers are mainly within $30-38 \mathrm{~m}$, whereas the depths of the other wells that penetrate mere weathered-regolith aquifers are mostly below $30 \mathrm{~m}$ (Table 1). Estimably, sustainable groundwater-bearing zones can be said to be within the depth range of 30-38 $\mathrm{m}$ within the amphibolite and gneissic terrains.

Comparatively, from the mean in Table 2, the regolith aquifers were characterised by lower transmissivity of $0.92 \mathrm{~m}^{2} /$ day and higher total drawdown of $18.08 \mathrm{~m}$, compared to $9.15 \mathrm{~m}^{2} /$ day and $5.42 \mathrm{~m}^{2} /$ day with a total drawdown of $10.27 \mathrm{~m}$ and $16.90 \mathrm{~m}$ for dual and leaky aquifers respectively. The regolith 


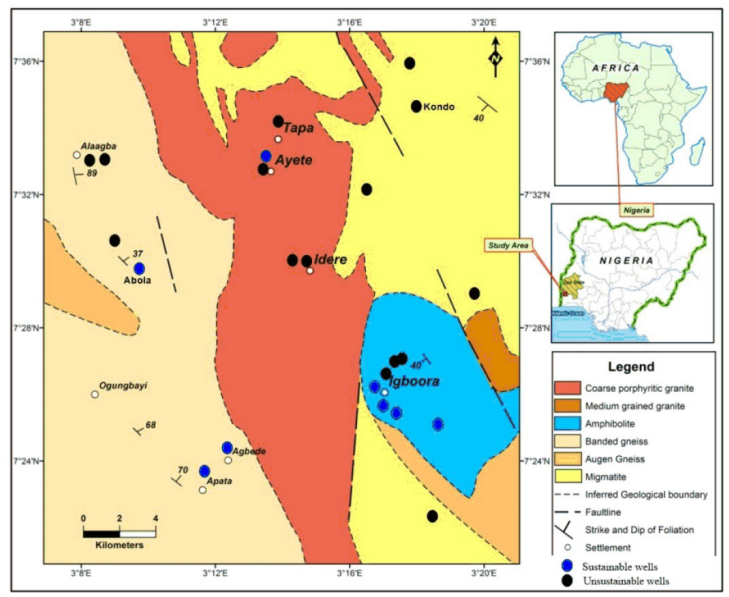

Figure 8: Locations of sustainable and unsustainable wells on geological map.

aquifers can be said to be terminated on either impermeable or sparsely fractured bedrock (or boundary). Hence, the drawdown drops drastically, and the yield is not sustainable for a long period of pumping. The discharge in the regolith aquifers was mostly influenced by well bore storage. The regolith aquifers are unsustainable and are the most widespread category, but they are usually associated with migmatite and granitic terrains (Figure 8).

\section{Conceptual Models of Hydraulic Settings of the Aquifer Systems}

The overall theoretical model of the hydraulic conditions of the basement aquifer of the Ibarapa region based on the plots of transmissivity against groundwater yield can be categorised into four major groups as illustrated in Figure 9. Groups A and B are regolith aquifers whose hydrogeological settings could not sustain a longer pumping period. However, the seven wells in Group B were characterised by large groundwater discharge greater than $70 \mathrm{~m}^{3} /$ day, but the yield is unsustainable over a long period. The discharge drops as pumping continues. The transmissivities of the aquifers in this group are typically greater than $1.0 \mathrm{~m}^{2} /$ day. Contrastingly, the transmissivities of the aquifers of under Group A are mostly below $1.0 \mathrm{~m}^{2} /$ day. Groundwater yield is lower and less than $60 \mathrm{~m}^{3} /$ day, but the aquifers can sustain a longer period of discharge.

The hydrogeological settings of eight aquifers in Groups C and D sustained continuous

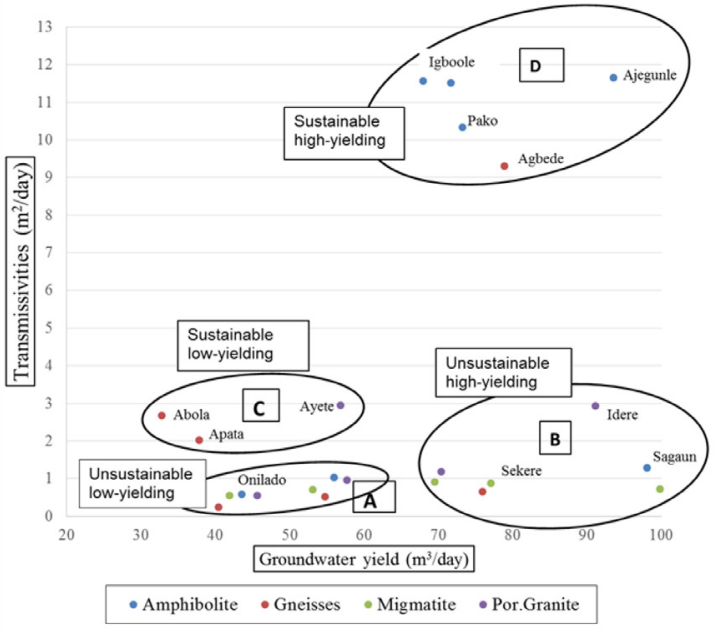

Figure 9: Conceptual hydraulic models of basement aquifers across the study area.

groundwater yield for hours of pumping. But in comparison, aquifers in Group C have lower transmissivities and smaller sustainable discharge than those in Group D (Figure 9). The transmissivities of aquifers in Group D exceeded $9.0 \mathrm{~m}^{2} /$ day and their discharge above $60 \mathrm{~m}^{3} /$ day. Lastly, migmatite and granitic aquifers are mainly regolith/weathered units whose yields are not sustainable either when large or when low. These aquifers can only sustain short pumping period, which may be lengthened when the bedrock is fractured. Wells in Groups C and D are typically within amphibolite and gneisses terrains, where the bedrocks are largely fractured [12].

\section{Conclusion}

For sustainable groundwater development, the groundwater system should be used in a way that it can be conserved for an unlimited time without causing improper environmental, economic or social problems [17]. It is obvious from the responses of the basement aquifers to pumping that geological and structural heterogeneity have imprinted on the hydraulic settings across the study area. The subsurface groundwater-bearing zones in Igboora and the lower parts of the western block within the study area are sustainable and quite pro- 
lific. These areas are underlain by amphibolite and gneisses, respectively. Wells drilled within these areas can be connected to provide town water supply for the entire Ibarapa region. This will ensure even distribution and judicious utilisation of groundwater system for the entire Ibarapa region, including areas such as Ayete and Tapa that are underlain by migmatite and granite where the water-bearing zones are not able to sustain a long period of pumping. Alternatively, groundwater may also be exploited from the overburden units within the latter areas through hand-dug wells. Although the yield will be low and will be adversely affected by seasonal variation during dry season, this will improve through meteoric recharge during the recurrent rainy season.

\section{References}

[1] Acworth, R.I. (1987): The development of crystalline basement aquifers in a tropical environment. Quarterly Journal of Engineering Geology, 20, pp. 265-272.

[2] Wright, E.P., Burgess, W.G. (1992): Hydrogeology of crystalline basement aquifers in Africa. Geological Society Special Publication, 66, pp. 1-27.

[3] Akanbi, O.A. (2016): Use of vertical electrical geophysical method for spatial characterisation of groundwater potential of crystalline crust of Igboora area, southwestern Nigeria. International Journal of Scientific and Research Publications, 6(3), pp. 399-406.

[4] Akanbi, O.A. (2017): Hydrogeologic characterisation of crystalline basement aquifers of part of Ibarapa area, southwestern Nigeria. Ph. D. Thesis. University of Ibadan, Faculty of Science, Department of Geology: Ibadan, $312 \mathrm{p}$.

[5] [5] Akanbi, O.A., Olukowade, J.0 (2018): Lithologic Characterisation of the Basement Aquifers of Awe and Akinmorin Areas, Southwestern Nigeria. Global journal of geological sciences, 16, pp. 1-11, DOI: 10.4314/gjgs.v16i1.1.

[6] Dada, S.S. (1998): Crust-forming ages and Proterozoic evolution in Nigeria: a reappraisal of current interpretations. Precambrian Research, 87, pp. 65-74.

[7] NGSA, (2009): Geological and mineral resources map of south-western zone, Nigeria. Nigerian Geological Survey Abuja, Nigeria.
[8] 2006 population census [online]. National Bureau of Statistics [cited 7/26/2011]. Available on: http:// www.nigerianstat.gov.ng.

[9] Singhal, B.B.S., Gupta R.P. (1999): Applied hydrogeology of fractured rocks. Kluwer Academic Publishers: Dordrecht, $400 \mathrm{p}$.

[10] Kruseman, G.P., de Ridder, N.A. (2000): Analysis and evaluation of pumping test data. $2^{\text {nd }}$ edition. International institute for land reclamation and improvement: Wageningen, $377 \mathrm{p}$.

[11] Jones, H.A., Hockey, R.D. (1964): The geology of part of south-western Nigeria. Bull. Geol. Surv. Nigeria, 31.

[12] Akanbi, O.A. (2018): Hydrogeological characterisation and prospects of basement aquifers of Ibarapa region, SW Nigeria. Applied Water Science, 8(3), 89, DOI: 10.1007/s13201-018-0731-9.

[13] Phillippe, R., Damian, G., Miguel, M. (2008): Understanding diagnostic plots for well-test interpretation. Hydrogeology Journal, 17, pp. 589-600.

[14] Cooper, H.H., Jacob, C.E, (1946): A generalized graphical method for evaluating formation constants and summarising well field history. American Geophysical Union Transactions, 27, pp. 526-534.

[15] Fetter, C.W. (2007): Applied hydrogeology. $2^{\text {nd }}$ edition. Merrill Publishing Company: USA, 592 p.

[16] Akanbi, O. A. (2018): Groundwater Occurrence from Hydrogeomorphological Study of Hard Rock Terrain of part of SW Nigeria. Materials and Geoenvironment, 65(3), pp. 131-143, DOI: 10.2478/ rmzmag-2018-0011.

[17] Alley, W.M., Reilly, T.E., Franke O.L. (1999): Sustainability of groundwater resources. U.S. Geological Survey Circular 1186. 